УДК: 658.15

DOI: https://doi.org/10.32366/2523-4269-2020-72-3-125-134
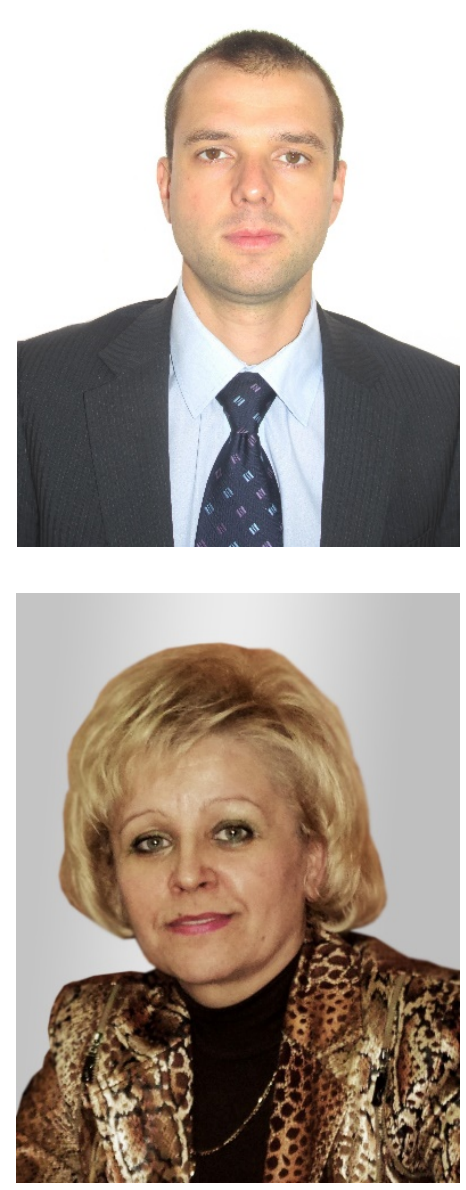

Кадала Віталій Віталійович, кандидат юридичних наук, доцент (Донечъкий юридичний інститут МВС України, м. Кривий Piг)

ORCID: https://orcid.org/0000-0002-6868-9487

Гузенко Олена Павлівна, кандидат економічних наук, доцент (Донецъкий юридичний інститут МВС України, м. Кривий Ріг) ORCID: https://orcid.org/0000-0003-4002-2629

\section{ОКРЕСЛЕННЯ ПИТАНЬ УПРАВЛІНСЬКОГО TА ПРАВОВОГО ЗМІСТУ В КОНТЕКСТI ЕКОНОМІЧНОЇ БЕЗПЕКИ ПІДПРИЕМСТВ}

Статтю присвячено питанням правового регулювання та удосконаленню системи розробки етапів управління економічною безпекою підприємств. Звернуто увагу на проблематичні аспекти в сучасних управлінсъких ииклах та обгрунтовано доиілъність перегляду їхнъӧ змістовності у разі оновлення правового регулятора в питаннях економічної безпеки. Представлено авторсъку точку зору щодо уточнення змістовності сутнісної характеристики понятійної категоріӥ "управління економічною безпекою підприємств" та

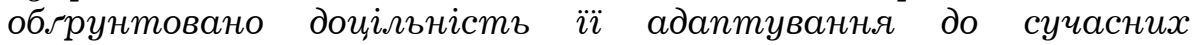
управлінсъких прочесів. Запропоновано впровадження в систему управління економічною безпекою підприємств етапу бормування інформаиійно-правового ресурсу операиійного сегменту. Наведено авторсъке бачення змістовності дій виконавия на етапі бормування інбормачійно-правового ресурсу операиійного сегменту та розкрито його роль у загальній системі управління економічною безпекою підприємства. Надано пропозичї щодо покращення системи управління економічною безпекою підприємств з огляду на наявні кризові явища в економіиі країни.

Ключові слова: економічна безпека; правовий інструмент; система управління; етапи управління; підприємство; управлінсъкий иикл; інбормаиійно-правовий ресурс; управління економічною безпекою.

Постановка проблеми. Економічна безпека підприємств $\epsilon$ проблематичним та дискусійним питанням 3 огляду на сучасні виклики, які супроводжують фінансовоекономічні та соціально-економічні процеси в країні. Кризові явища в підприємницькому секторі країни висувають вимоги щодо доцільності та оновлення управлінських циклів із позиції економічної безпеки. Підприємства великого, середнього та малого бізнесу практично є незахищеними від впливу змін у правовому полі та конкурентному середовищі відповідної сфери їхнього функціонування. Постає питання збереження вже наявних досягнень та раціонального використання власного ресурсного потенціалу. Безумовно, вирішення поставленої проблеми лежить у площині підтримки представників підприємницького сектору як з боку країни через законодавчі інструменти, так і з боку 
вищого менеджменту підприємств через вдосконалення управлінського циклу в контексті економічної безпеки. На жаль, сучасна підприємницька діяльність доводить, що підприємства потерпають від значного податкового тиску, непередбачених інфляційних коливань, поступового зросту курсу валют та комунальних платежів. Проте вважати зазначені негативні чинники єдиними впливовими сегментами недоречно, тому що значна кількість підприємств не приділяє належної уваги системі управління економічною безпекою i, як наслідок, постійно втрачає певну частину економічної вигоди. 3 викладеного вище постає нагальна проблема, яку доцільно вирішувати шляхом оновлення системи управління економічною безпекою вищим менеджментом підприємств. Ідеться про впровадження інноваційних підходів під час розробки етапів управлінського циклу на основі змін, що регламентовано макроекономічним рівнем на час формування цієї системи. Таке явище підтверджує сучасність та актуальність обраного напрямку дослідження.

Актуалізація поставленої проблеми грунтується на доцільності адаптування інноваційних змін у роботі вищого та середнього менеджменту підприємств, який займається питаннями економічної безпеки. Водночас потребує оновлення сама управлінська система 3 позиції деталізації та взаємозв'язку між етапами, які входять до їі складу. Для надання більш предметної характеристики системі управління економічною безпекою сучасних підприємств потребує уточнення понятійний апарат. Наявність інноваційного підходу до поставленої проблеми свідчить про актуальність вивчення кола питань для її вирішення.

Аналіз останніх досліджень i публікацій. Проблема економічної безпеки підприємств не $є$ новою, проте залишається актуальною в наукових дослідженнях та постійно розглядається представниками підприємницького сектору економіки країни як ключове питання, що потребує негайного вирішення. Формуванню та дослідженню наукових i методичних засад системи управління економічною безпекою підприємств присвятили монографічні праці такі науковці, як: 3. Б. Живко [1], О. В. Ілляшенко [2], С. В. Кавун [3], М. М. Караїм, В. В. Мартинів, А. М. Штангрет та ін. [4], О. М. Ляшенко [5], О. В. Пабат [6], С. В. Філиппова, Л. О. Волощук, С. О. Черкасова [7]. Учені вважають, що система управління економічною безпекою підприємств має спиратися на інноваційні сегменти, які найбільш здатні підвищити і зміцнити ऑї рівень. Разом 3 тим звертають увагу на недостатність вивчення питань змістовності управлінських етапів цієї системи. Дискусійним у наукових колах залишається питання методологічної змістовності процесу оцінювання рівня економічної безпеки підприємств, який виступає одним із сегментів управлінського циклу. За цих умов слід віддати належне науковим розробкам вітчизняних учених, а саме: Б. М. Мізюка, В. І. Ящук та Л. В. Ноздріної [8] О. В. Нусінової [9], О. В. Россошанської [10]. Цінність їхніх наукових досліджень полягає в розробці доволі різноманітних підходів як до загального процесу оцінювання рівня економічної безпеки підприємств, так і до окремих його сегментів. Водночас науковці підкреслюють існування проблематичного аспекту в системі формування інформаційного потоку для процесів оцінювання 3 огляду на доволі часті зміни в макроекономічному середовищі.

Метою дослідження $є$ окреслення питань управлінського та правового змісту в контексті економічної безпеки підприємств із визначенням напрямків іiі зміцнення. Досягнення поставленої мети зумовлює вирішення таких завдань: визначити проблематичні аспекти сучасної системи управління економічною безпекою підприємств; надати уточнення змістовності сутнісної характеристики понятійної категорії «управління економічною безпекою підприємств» та обгрунтувати доцільність їі адаптування в сучасних управлінських процесах; розробити пропозиції щодо покращення структури системи управління предметом дослідження із визначенням напрямку його зміцнення.

Виклад основного матеріалу. Сучасні підприємства опинилися в умовах впливу ряду деструктивних факторів зовнішнього середовища — правового, економічного, соціального та 
політичного характеру, які породжують низку потенційних і наявних небезпек та загроз, що знижують рівень економічної безпеки підприємства та ставлять під сумнів перспективність його подальшої ефективної діяльності. Реалії сьогодення вказують на доцільність та необхідність перегляду підприємствами підходів до розробки системи управління економічною безпекою, тому що наявні управлінські цикли не витримують постійних змін, $\mathrm{i}$ як наслідок - не виконують в повному обсязі поставлену мету їхнього існування.

За результатами дослідження встановлено, що доволі проблематичним етапом управлінського циклу є інформаційний базовий сегмент, який покладено в основу прийняття управлінських рішень. Стає зрозумілим той факт, що низька якість інформаційного пакету для оцінювання рівня економічної безпеки підприємств призводить до прийняття хибних рішень.

Вважаємо, що одним із напрямків покращення управлінської системи має стати оновлення етапів її практичної адаптації з чітко визначеними термінами обробки даних із позиції оцінювання рівня економічної безпеки. Проте на першому етапі доцільно звернутися до існуючих наукових позицій щодо сутнісного змісту понятійної категорії «управління економічною безпекою підприємств». Така позиція обгрунтовується тим, що без чіткого розуміння змістовності процесу, який потребує інноваційного втручання, його понятійної бази досягти достатнього рівня результативності в управлінському циклі практично неможливо.

Зокрема, О.Ф. Ярошенко пропонує визначати змістовність категорії «управління економічною безпекою» в об'єктному, суб'єктному та інструментальному аспектах [11]. Автор звертає увагу на те, що об'єктний аспект економічної безпеки зосереджений на вивченні об'єктів системи, а суб'єктний та інструментальний — на принципах стратегічного управління такими процесами. Науковець уточнює той факт, що саме «...суб'єктний аспект виділяє організаційні та стратегічні здатності підприємства для створення стану захищеності та виокремлює таку характеристику, як компетентність підприємства». Водночас О. Ф. Ярошенко наголошує на тому, що «...інструментальний аспект розглядає економічну безпеку як функцію управління підприємством, i тому зосереджує увагу на методах, моделях, способах та заходах щодо забезпечення захисту його діяльності» [11].

У свою чергу, І. П. Мойсеєнко та О. О. Шолок стверджують, що «...процес забезпечення фінансово-економічної безпеки підприємства базується на відповідному механізмі ii управління, під яким розглядають сукупність станів та процесів, 3 яких складається управління щодо протидії небезпекам, загрозам та ризикам» [12]. Безумовно, економічна безпека підприємства є складним, динамічним явищем, яке потребує розробки такого механізму управління, який враховував би всі іiі характеристики та умови функціонування суб'єкта господарювання.

Узагальнення результатів дослідження вітчизняних учених [13-15] показало, що науковці пропонують понятійну категорію «управління економічною безпекою підприємств» розглядати як «...систему принципів і методів розробки та реалізації управлінських рішень, що пов'язані із забезпеченням захисту його економічних інтересів від внутрішніх і зовнішніх загроз». Водночас О. Л. Коробчинський вважає, що дефініція «управління економічною безпекою підприємств» має такий зміст: комплекс організаційно-управлінських, технологічних, технічних, профілактичних i маркетингових заходів, спрямованих на кількісну та якісну реалізацію захисту інтересів підприємства від зовнішніх і внутрішніх загроз [16].

Дослідження показали, що питання трактування понятійної категорії «управління економічною безпекою підприємств» залишається у сфері дискусійних наукових позицій, проте обмежено торкається самого принципу управління, котрий має стати домінантною складовою. Ми вважаємо, що розкриття сутності цієї категорії має відбуватися 3 
урахуванням правил поведінки керуючої та керованої системи. Таке твердження грунтується на пріоритетній участі самих виконавців, які мають забезпечити дієвість управлінського циклу. 3 огляду на зазначене вище пропонуємо таке тлумачення понятійної категорії «управління економічною безпекою підприємств»: механізм взаємозв'язку керуючої та керованої системи підприємства, який здатен адаптувати інноваційну методологічну основу оцінювання економічної безпеки та спроможний синтезувати рішення у сфері протидії небезпеці, загрозам та ризикам, що супроводжують операційний сектор діяльності. На нашу думку, обгрунтування запропонованої сутнісної характеристики понятійної категорії «управління економічною безпекою підприємств» розглядається у такій площині:

- без тісного взаємозв'язку між керуючою та керованою системою управління рівнем економічної безпеки підприємства неможливо забезпечити дієвість усіх управлінських сегментів та уникнути дублювання функціональних обов'язків безпосередніх виконавців, котрі є представниками як вищої, так і середньої управлінської ланки;

— обрані методи та способи обробки інформації для проведення оцінювання рівня економічної безпеки підприємства повинні спиратися на сучасну методологічну базу 3 урахуванням інноваційного інструментарію, який має за основу новітні інструменти та підходи;

— про результативність дій виконавців у системі управління економічною безпекою підприємства свідчать рішення у сфері протидії небезпеці, загрозам та ризикам, які супроводжують операційний сектор діяльності. Саме операційна діяльність підприємств виступає базою для отримання певного рівня прибутковості, ліквідності, фінансової стійкості та конкурентоспроможності.

Практична діяльність представників підприємницького сектору країни свідчить про те, що сучасна система управління економічною безпекою підприємств повинна бути гнучкою, інтегрованою та відкритою; такою, що охоплює принципи, інноваційні прийоми і способи, методи й методики, процедури, алгоритми та моделі, за допомогою яких забезпечується узгодження інтересів підприємства 3 інтересами взаємодіючих із ним суб'єктів зовнішнього середовища.

Доволі проблемним питанням для сучасного підприємства $є$ залежність від законодавчих регуляторів, які зазнають не завжди раціональних змін. У системі управління економічною безпекою сучасних підприємств зазначений фактор негативно впливає на формування інформаційної бази для прийняття управлінських рішень. Ми вважаємо сам процес накопичення інформаційного ресурсу керованою системою, тому він повинен мати інноваційну платформу. Ідеться про доцільність адаптування етапу формування інформаційно-правового ресурсу операційного сегменту до системи управління економічною безпекою сучасних підприємств. Перш ніж визначити місце цього етапу в управлінському циклі, варто розглянути правові регулятори, які є носіями накопичування названого інформаційного ресурсу.

В основу інформаційного ресурсу покладено правові регулятори, які пов'язані із забезпеченням економічної безпеки країни взагалі та окремого підприємства. Правова сфера може нести загрози, спричинені нестабільністю чинного законодавства, неврегульованістю низки аспектів діяльності підприємств, недосконалістю правових механізмів регулювання окремих господарських відносин, непоміркованістю змін у законодавстві, копіюванням норм міжнародного законодавства без належної їх адаптації до вітчизняних реалій, а також недосконалістю системи правосуддя, і як наслідок - недостатня захищеність права власності, обмежені можливості щодо оскарження недійсних правочинів. Крім того, недоліком чинного законодавства $\epsilon$ те, що загрози економічній безпеці розглядаються лише в межах національної безпеки, при цьому загрози економічній безпеці держави не систематизовано за окремими складовими економічної безпеки як держави, так i 
підприємств, що визначені Методичними рекомендаціями щодо розрахунку рівня економічної безпеки України [17].

За результатами проведених досліджень можна стверджувати, що особливе місце в системі актів щодо забезпечення економічної безпеки мають програмні установчі документи: стратегії, концепції, доктрини - які становлять систему офіційно прийнятих у державі регуляторів (оскільки є установчими). До їхнього складу належать:

- Стратегія сталого розвитку «Україна - 2020» (Основні положення): Указ Президента України від 15.01.2015 № 5/2015 [18];

- Стратегія національної безпеки України: Указ Президента України від 26 травня 2015 року № 287/2015 [19];

- Про Концепцію боротьби з тероризмом в Україні: Указ Президента України № 53/2019 від 05.03.2019 [20];

- Воєнна доктрина України: Указ Президента України від 24 вересня 2015 року № 555/2015 [21] та низка інших.

Провідну роль у правових регуляторах законодавець відводить Закону України «Про національну безпеку України», який було прийнято 21 червня 2018 року [22]. Закон визначає основи та принципи національної безпеки й оборони, а також засади державної політики в цьому напрямі.

3 позиції підприємницьких структур правовими базовими регуляторами виступають окремі статті Кодексів України: Бюджетного, Податкового, Господарського, Митного та інших. Окреслені правові інструменти створюють правила ведення підприємницької діяльності, мають вплив на формування стратегії i тактики управління економічною безпекою та надають можливість уникнути штрафних санкцій у разі нехтування законодавчими положеннями.

Повертаючись до предмета дослідження, зазначимо, що класично система управління економічною безпекою підприємств складається 3 таких етапів: визначення цілей та місії діяльності підприємства на основі проведеного моніторингу зовнішніх та внутрішніх загроз; аналіз зібраної інформації з позиції об’єкта захисту та агентів впливу на економічну безпеку; оцінка економічної безпеки за такими складовими елементами, як: політико-правовий, виробничо-технічний, фінансово-економічний, екологічний, інформаційний, силовий та кадровий; розробка заходів із мінімізації та нейтралізації впливу негативних факторів на рівень економічної безпеки підприємства на основі вибору інструментів та засобів захисту: правових, фінансово-економічних, техніко-технологічних, інноваційних, силових та інформаційних; визначення повноважень виконавців і центрів відповідальності представників вищого та середнього менеджменту у сфері забезпечення визначеного планового рівня економічної безпеки; упровадження системи управління економічною безпекою підприємства. Як ми вже зауважували, важливого значення набуває забезпечення економічної безпеки підприємства для великих підприємств, розташованих у потужних промислових регіонах [23, 24].

Враховуючи зазначене, ми вважаємо, що сучасне підприємство з огляду на сучасні реалії має розширити перелік ключових етапів за рахунок упровадження етапу формування інформаційно-правового ресурсу операційного сегменту. До того ж в основу накопичувального ресурсу пропонуємо включити всі правові інструменти, які впливають саме на операційну діяльність підприємства. Така теза $є$ наслідком того, що цей вид діяльності підприємств є не лише носієм найбільшої частини економічної вигоди, а й виступає як ключовий сегмент, який має найбільший рівень економічного ризику під впливом існуючих негативних факторів, що безпосередньо знижують рівень економічної безпеки діяльності підприємства. До складу дій безпосередніх виконавців цього управлінського етапу, на нашу думку, належать: оцінка існуючих змін у законодавчих регуляторах, які залучені до операційної діяльності підприємства; формування 
інформаційного блоку з урахуванням встановлених змін; визначення рівня впливу правових змін на існуючий стратегічний та тактичний управлінський цикл, який вже адаптовано підприємством відповідно до економічної безпеки; розробка пропозицій щодо впровадження цих змін із метою внесення поправок до наявних та затверджених підприємством сегментів операційної діяльності. Ми вважаємо, що це надасть можливість підприємству уникнути хибного ціноутворення на продукцію, роботи, послуги та своєчасно виконати вимоги законодавця.

3 позиції змістовності пропонується етап формування інформаційно-правового ресурсу операційного сегменту розуміти як комплексний інформаційно-правовий накопичувач, сформований 3 урахуванням принципів системності, об'єктивності, своєчасності, повноти та достовірності інформації, орієнтації на результат із метою уникнення негативного впливу на рівень економічної безпеки операційної діяльності підприємств. Обгрунтуванням саме такої пропозиції є:

- операційна діяльність підприємства постійно обирається законодавцем у разі впровадження змін податкового спрямування, які належать до циклів ціноутворення;

- відбувається врахування принципів формування накопичувального ресурсу, що є позитивним моментом у контексті виконання функціональних обов'язків безпосереднім виконавцем;

- зберігається головне завдання управлінського циклу щодо зниження негативного впливу на рівень економічної безпеки підприємства.

Висновки. Одержані наукові результати дали змогу розв'язати окремі аспекти актуального наукового завдання, що має важливе значення для розвитку системи управління економічною безпекою підприємств, зокрема уточнено змістовність цієї системи як понятійної категорії (механізм взаємозв'язку керуючої та керованої системи підприємства, який здатен адаптувати інноваційну методологічну основу оцінювання економічної безпеки та спроможний синтезувати рішення у сфері протидії небезпеці, загрозам та ризикам, які супроводжують операційний сектор діяльності), запропоновано зміни у складі елементів цього управлінського циклу в контексті адаптування етапу формування інформаційно-правового ресурсу операційного сегменту 3 визначенням змістовності (комплексний інформаційноправовий накопичувач сформований з урахуванням принципів системності, об'єктивності, своєчасності, повноти та достовірності інформації, орієнтації на результат з метою уникнення негативного впливу на рівень економічної безпеки операційної діяльності підприємств) та обгрунтовано доцільність їхньої адаптації. Встановлено, що система управління економічною безпекою підприємства є складним та багатовимірним процесом, від якого залежить його стійкий розвиток та захищеність від загроз і небезпек. До складу ключових напрямків зміцнення економічної безпеки підприємств пропонуємо включити постійний моніторинг змін правового регулятора, який впливає на умови функціонування підприємства; провести вдосконалення управлінського циклу на основі запропонованих понятійних категорій 3 урахуванням змін у його структурі; розширити повноваження виконавців та підвищити рівень відповідальності за своєчасність адаптування змін, які впливають на рівень економічної безпеки; постійне проведення моніторингу кожного управлінського етапу з метою дотримання визначеного стратегічного та тактичного рівня економічної безпеки; забезпечити постійне оновлення пакету заходів, націлених на зміцнення економічної безпеки та покращення роботи всіх управлінських ланок підприємства.

Перспективи подальшого дослідження вбачаємо в розробці прикладних заходів із позиції визначення впливу змін правових регуляторів на виконання визначеного рівня економічної безпеки підприємства, який передбачено в наявних стратегічних та управлінських циклах. 


\section{Список використаних джерел}

1. Живко 3. Б. Методологія управління економічною безпекою підприємства : монографія. Львів: Ліга-Прес, 2013. 471 с.

2. Ілляшенко О.В. Механізми системи економічної безпеки підприємства : монографія. Харків: Мачулін, 2016. 503 с.

3. Кавун С. В. Економічна безпека підприємства: інформаційний аспект : монографія. Харків: Щедра садиба плюс, 2014. 311 с.

4. Антикризові технології в управлінні економічною безпекою підприємства : монографія / М. М. Караїм, В. В. Мартинів, А. М. Штангрет та ін.; за заг. ред. А. М. Штангрета. Л.: Укр. акад. друкарства, 2016. 250 с.

5. Ляшенко О.М. Концептуалізація управління економічною безпекою підприємства : монографія [2-ге вид., переробл.]. К.: НІСД, 2015. 348 с.

6. Пабат О. В. Економічна безпека держави: інноваційні фактори : монографія. Львів: Інс-т регіональних досліджень НАН України, 2012. 168 с.

7. Економічна безпека підприємств реального сектору економіки в умовах вартісноорієнтованого управління : монографія / С. В. Філиппова, Л.О.Волощук, С. О. Черкасова; ред. С. В. Філіппова. Одеса: Апрель: ФОП Бондаренко М. О. 2015. 195 с.

8. Мізюк Б. М., Ящук В. І., Ноздріна Л. В. Економічна безпека підприємств ритейлу: оцінювання та механізм забезпечення : монографія. Л.: Центр. спілка спожив. т-в України, Львів. комерц. Акад., 2012. 255 с.

9. Нусінова О. В. Основи оцінки економічної безпеки підприємств: теоретичні та практичні аспекти : монографія. К.: ПанТот, 2012. 411 с.

10. Россошанська О. В. Оцінювання економічної безпеки інноваційних проектно-орієнтованих підприємств : монографія. Сєвєродонецьк: Східноукр. нац. ун-т ім. В. Даля, 2016. 349 с.

11. Ярошенко О. Ф. Управління економічною безпекою підприємства: дис. ... канд. екон. наук : 08.00.04. Х.: Харківський нац. екон. ун-т, 2013. 23 с.

12. Мойсеєнко І. П., Шолок О. О. Механізм управління фінансово-економічною безпекою підприємства. Науковий вісник НЛТУ Украйни : збірник науково-технічних праць. Львів: РВВ НЛТУ України. 2011. Вип. 21.02. С. 141-146.

13. Алькема В.Г. Аналіз системи економічної безпеки суб'єктів господарської діяльності. Фінансова система України. Наукові записки. Серія «Економіка». 2012. № 16. С. 99-107.

14. Економічна безпека в умовах глобалізації світової економіки : колективна монографія у 2 т. Дніпропетровськ: «ФОП Дроб’язко С. І.», 2014. Т. 1. 466 с.

15. Момот Т. В., Філатова I. О., Тофанюк О. В. Економічна безпека корпоративних підприємств будівельної галузі. Економіка та управління підприємствами машинобудівної галузі: проблеми теорії та практики. 2011. № 2 (14). С. 14-26.

16. Коробчинський О. Л. Методика формування системи економічної безпеки підприємства. Актуальні проблеми економіки. 2009. № 4 (94). С. 41-45.

17. Про затвердження Методичних рекомендацій щодо розрахунку рівня економічної безпеки України : Наказ Міністерства економічного розвитку і торгівлі України від 29.10.2013 № 1277. URL: https://zakononline.com.ua/documents/show/218014__218079 (дата звернення: 20.07.2020)

18. Стратегія сталого розвитку «Україна - 2020» : Указ Президента України від 15.01.2015 № 5/2015. Офіційний вісник України від 23.01.2015. 2015. № 4. С. 8. Ст. 67, код акта 75358/2015.

19. Стратегія національної безпеки України : Указ Президента України від 26 травня 2015 р. № 287/2015. Офіційний вісник України. 2015. № 43. С. 14. Ст. 1353.

20. Про Концепцію боротьби з тероризмом в Україні : Указ Президента України № 53/2019 від 05.03.2019. Офіційний вісник України від 15.03.2019. 2019. № 21. С. 24. Ст. 710, код акта 93690/2019.

21. Воєнна доктрина України : Указ Президента України від 24 вересня 2015 року № 555/2015. Офіційний вісник України від 09.10.2015. 2015. № 78. С. 38. Ст. 2592, код акта 78728/2015.

22. Про національну безпеку України : Закон України від 21.06.2018 № 2469-VIII. URL: https://zakon.rada.gov.ua/laws/show/2469-19 (дата звернення: 20.07.2020)

23. Правове регулювання економічних відносин за участі підприємств великого промислового регіону : монографія / Деревянко Б. В. та ін. Львів: «Магнолія 2006», 2020. 245 с. 
24. Кадала В. В., Гузенко О. П., Павліченко Є. В.Концептуальні та організаційно-правові засади забезпечення безпеки України : навч. посіб. ДЮІ МВС України. Львів: «Магнолія 2006», 2020. 194 с.

\section{References}

1. Zhyvko, Z. B. (2013). Metodolohiia upravlinnia ekonomichnoiu bezpekoiu pidpryiemstva : monohrafiia [Methodology of economic security management of the enterprise : monograph]. Lviv: LihaPres. 471 s. [in Ukrainian].

2. Illiashenko, O. V. (2016). Mekhanizmy systemy ekonomichnoi bezpeky pidpryiemstva : monohrafiia [Mechanisms of the system of economic security of the enterprise : monograph]. Kharkiv: Machulin. 503 s. [in Ukrainian].

3. Kavun, S. V. (2014). Ekonomichna bezpeka pidpryiemstva: informatsiinyi aspekt : monohrafiia [Economic security of the enterprise: information aspect : monograph]. Kharkiv: Shchedra sadyba plius. 311 s. [in Ukrainian].

4. Antykryzovi tekhnolohii v upravlinni ekonomichnoiu bezpekoiu pidpryiemstva : monohrafiia [Anti-crisis technologies in the management economy of the enterprise : monograph]; za zah. red. A. M. Shtanhreta (2016). L.: Ukr. akad. Drukarstva. 250 s. [in Ukrainian].

5. Liashenko, O. M. (2015). Kontseptualizatsiia upravlinnia ekonomichnoiu bezpekoiu pidpryiemstva : monohrafiia [Conceptualization of management of economic security of the enterprise : monograph]. K.: NISD. 348 s. [in Ukrainian].

6. Pabat, O. V. (2012). Ekonomichna bezpeka derzhavy: innovatsiini faktory : monohrafiia [Economic security of the state: innovative factors : monograph]. Lviv: Ins-t rehionalnykh doslidzhen NAN Ukrainy. 168 s. [in Ukrainian].

7. Ekonomichna bezpeka pidpryiemstv realnoho sektoru ekonomiky $\mathrm{v}$ umovakh vartisnooriientovanoho upravlinnia : monohrafiia (2015) [Economic security of enterprises of the real sector of the economy in terms of cost-oriented management : a monograph]; red. S. V. Filippova. Odesa: Aprel: FOP Bondarenko M. O. 195 s. [in Ukrainian].

8. Miziuk, B. M., Yashchuk, V. I., Nozdrina, L. V. (2012). Ekonomichna bezpeka pidpryiemstv ryteilu: otsiniuvannia ta mekhanizm zabezpechennia : monohrafiia [Economic security of retail enterprises: evaluation and support mechanism : monograph]. L.: Tsentr. spilka spozhyv. t-v Ukrainy, Lviv. komerts. Akad. 255 s. [in Ukrainian].

9. Nusinova, O. V. (2012). Osnovy otsinky ekonomichnoi bezpeky pidpryiemstv: teoretychni ta praktychni aspekty : monohrafiia. [Fundamentals of economic security assessment of enterprises: theoretical and practical aspects : monograph] K.: PanTot. 411 s. [in Ukrainian].

10. Rossoshanska, O. V. (2016). Otsiniuvannia ekonomichnoi bezpeky innovatsiinykh proektnooriientovanykh pidpryiemstv : monohrafiia. [Assessment of economic security of innovative project-oriented enterprises : a monograph]. Sievierodonetsk: Skhidnoukr. nats. un-t im. V. Dalia. 349 s. [in Ukrainian].

11. Yaroshenko, O. F. (2013). Upravlinnia ekonomichnoiu bezpekoiu pidpryiemstva : dys. ... kand. ekon. nauk : 08.00.04 [Management of economic security of the enterprise]. Kh.: Kharkivskyi nats. ekon. unt. 23 s. [in Ukrainian].

12. Moiseienko, I. P., Sholok, O. O. (2011). Mekhanizm upravlinnia finansovo-ekonomichnoiu bezpekoiu pidpryiemstva [The mechanism of management of financial and economic security of the enterprise]. Naukovyi visnyk NLTU Ukrainy: zbirnyk naukovo-tekhnichnykh prats. Lviv: RVV NLTU Ukrainy. Vyp. 21.02. S. 141-146 [in Ukrainian].

13. Alkema, V. H. (2012). Analiz systemy ekonomichnoi bezpeky subiektiv hospodarskoi diialnosti [Analysis of the system of economic security of economic entities]. Finansova systema Ukrainy. Naukovi zapysky. Seriia «Ekonomika». № 16. S. 99-107 [in Ukrainian].

14. Ekonomichna bezpeka v umovax globalizaciyi svitovoyi ekonomiky : kolekty`vna monografiya u 2 t. (2014) [Economic security in the context of globalization of the world economy]. Dnipropetrovs`k: «FOP Drobyazko S. I.». T. 1. 466 s. [in Ukrainian].

15. Momot, T. V., Filatova, I. O., Tofaniuk, O. V. (2011). Ekonomichna bezpeka korporatyvnykh pidpryiemstv budivelnoi haluzi [Economic security of corporate enterprises in the construction industry]. 
Ekonomika ta upravlinnia pidpryiemstvamy mashynobudivnoi haluzi: problemy teorii ta praktyky. № 2 (14). S. 14-26 [in Ukrainian].

16. Korobchynskyi, O. L. (2009). Metodyka formuvannia systemy ekonomichnoi bezpeky pidpryiemstva [Methods of forming the system of economic security of the enterprise]. Aktualni problemy ekonomiky. № 4 (94). S. 41-45 [in Ukrainian].

17. Pro zatverdzhennia Metodychnykh rekomendatsii shchodo rozrakhunku rivnia ekonomichnoi bezpeky Ukrainy [About the statement of Methodical recommendations concerning calculation of level of economic safety of Ukraine] : Nakaz Ministerstva ekonomichnoho rozvytku i torhivli Ukrainy vid 29.10.2013 № 1277. URL: https://zakononline.com.ua/documents/show/218014_ 218079 (data zvernennia: 20.07.2020) [in Ukrainian].

18. Stratehiia staloho rozvytku «Ukraina - 2020» [Sustainable Development Ukraine Strategy 2020] : Ukaz Prezydenta Ukrainy vid 15.01.2015 № 5/2015. Ofitsiinyi visnyk Ukrainy vid 23.01.2015, № 4. S. 8. St. 67, kod akta 75358/2015 [in Ukrainian].

19. Stratehiia natsionalnoi bezpeky Ukrainy [National Security Strategy of Ukraine] : Ukaz Prezydenta Ukrainy vid 26 travnia 2015 r. № 287/2015. Ofitsiinyi visnyk Ukrainy. № 43. S. 14. St. 1353 [in Ukrainian].

20. Pro Kontseptsiiu borotby z teroryzmom v Ukraini : Ukaz Prezydenta Ukrainy [On the Concept of Combating Terrorism in Ukraine : Decree of the President of Ukraine] № 53/2019 vid 05.03.2019. Ofitsiinyi visnyk Ukrainy vid 15.03.2019. № 21. S. 24. St. 710, kod akta 93690/2019 [in Ukrainian].

21. Voienna doktryna Ukrainy : Ukaz Prezydenta Ukrainy vid 24 veresnia 2015 roku № 555/2015 [Military doctrine of Ukraine]. Ofitsiinyi visnyk Ukrainy vid 09.10.2015. № 78. S. 38. St. 2592, kod akta 78728/2015 [in Ukrainian].

22. Pro natsionalnu bezpeku Ukrainy [About the national security of Ukraine] : Zakon Ukrainy vid 21.06.2018 № 2469-VIII. URL: https://zakon.rada.gov.ua/laws/show/2469-19 (data zvernennia: 20.07.2020) [in Ukrainian].

23. Pravove rehuliuvannia ekonomichnykh vidnosyn za uchasti pidpryiemstv velykoho promyslovoho rehionu : monohrafiia [Legal regulation of economic relations with the participation of enterprises of a large industrial region: a monograph] / za zah. red. B. V. Derevianka (2020). Lviv: «Mahnoliia 2006». 245 s. [in Ukrainian].

24. Kadala, V. V., Huzenko, O. P., Pavlichenko, Ye. V. (2020). Kontseptualni ta orhanizatsiinopravovi zasady zabezpechennia bezpeky Ukrainy : navch. posib. [Conceptual and organizational and legal principles of ensuring the security of Ukraine]. DIuI MVS Ukrainy. Lviv: «Mahnoliia 2006». 194 s. [in Ukrainian].

\author{
Kadala Vitaliy, \\ PhD of Law, Associate Professor \\ (Donetsk Law Institute, MIA of Ukraine, Kryvyi Rih) \\ ORCID: $h$ ttps://orcid.org/0000-0002-6868-9487 \\ Guzenko Olena, \\ $\mathrm{PhD}$ of Economy, Associate Professor \\ (Donetsk Law Institute, MIA of Ukraine, Kryvyi Rih) \\ ORCID: $h$ ttps://orcid.org/0000-0003-4002-2629
}

\title{
DEFINITION OF ISSUES OF MANAGEMENT AND LEGAL CONTENT IN THE CONTEXT OF ECONOMIC SECURITY OF ENTERPRISES
}

The article is devoted to the issues of legal regulation and improvement of the system of development of stages of economic security management of enterprises. Attention is paid to the existence of problematic aspects in modern management cycles and the expediency of revising their content, in case of updating the legal regulator in matters of economic security, is substantiated. Economic security of enterprises is a problematic and controversial issue given the current challenges that accompany the financial, economic and socioeconomic processes in the country. Crisis phenomena in the business sector of the country make demands on the feasibility and renewal of management cycles from the standpoint of economic security. Large, medium and small businesses are virtually vulnerable to changes in the legal field and the competitive environment of their respective areas of operation. There is a question of preservation of already existing achievements and rational use of own resource potential. The solution to this problem lies in the level of support for the business sector both by the country through legislative instruments and by senior management of enterprises through 
the improvement of the management cycle in the context of economic security. Modern business proves that companies suffer from significant tax pressures, unpredictable inflationary fluctuations, the gradual rise in exchange rates and utility bills. It is inappropriate to consider these negative factors as the only influential segments, as a significant number of enterprises do not pay due attention to the economic security management system, and as a result, constantly lose a certain part of economic benefits. From the above follows an urgent problem to be solved, namely: the feasibility of updating the economic security management system by senior management of enterprises. This means the introduction of innovative approaches in the development of stages of the management cycle based on changes, which is regulated by the macroeconomic level at the time of development of this system. The article presents the author's point of view on clarifying the content of the essential characteristics of the conceptual category of "management of economic security of enterprises" and substantiates the feasibility of its adaptation in modern management processes. The introduction and adaptation to the system of economic security management of enterprises of the stage of "formation of information and legal resources of the operating segment" is proposed. The author's vision of the content of the actions of the executor of the stage "formation of information and legal resources of the operating segment" is presented and its role aspect in the general management system of economic security of the enterprise is revealed. Proposals are made to improve the management system of economic security of enterprises in view of the existing crisis in the country's economy.

Key words: economic security; legal instrument; management system; stages of management; enterprise; management cycle; information and legal resource; management of economic security.

Надійшла до редколегії 14.08.2020

\section{Зразок для цитування:}

Кадала В.В., Гузенко О.П. Окреслення питань управлінського та правового змісту в контексті економічної безпеки підприємств. Правовий часопис Донбасу. 3 (72). 2020. C. 125-134. DOI: https://doi.org/10.32366/2523-4269-2020-72-3-125-134 